\title{
EVALUATING SURFACE WATER QUALITY AND TESTING FREQUENCY IN TIEN AND HAU RIVERS, AN GIANG PROVINCE, USING 10-YEAR MONITORING DATA
}

\author{
Nguyen Thanh Giao ${ }^{1}$
}

Abstract - The study aimed to assess the variation of surface water quality and evaluate the monitoring frequency at three continuous monitoring stations on the Tien river (MT1 station) and Hau river (MH1 and MH2 station) over a 10-year period (20092018), with a monitoring frequency of 12 times per year (monthly). The water quality variables comprised of temperature $\left({ }^{\circ} \mathrm{C}\right), \mathrm{pH}$, dissolved oxygen ( $D O, m g / L)$, total suspended solids (TSS, $\mathrm{mg} / \mathrm{L})$, nitrate $\left(\mathrm{N}-\mathrm{NO}_{3}^{-}, \mathrm{mg} / \mathrm{L}\right)$, orthophosphate $\left(P-\mathrm{PO}_{4}^{3-} \mathrm{mg} / \mathrm{L}\right)$, chemical oxygen demand (COD, $\mathrm{mg} / \mathrm{L})$, and coliforms $(M P N / 100 \mathrm{~mL})$. The individual water quality parameters were assessed by comparison with National Technical Regulation on surface water quality (QCVN 08-MT: 2015/BTNMT). Monitoring frequency was evaluated using Cluster Analysis (CA). The findings revealed that surface water on both Tien and Hau rivers was perpetually polluted with suspended solids, organic matter, nutrients, and microorganisms. The CA identified that the frequencies of current water monitoring could be reduced from 12 times to 5 times per year, resulting in a $58 \%$ reduction in monitoring costs. Future study should focus on evaluating water quality parameters to encompass all water quality characteristics in the Tien and Hau rivers. International collaboration with countries that impact the river before flowing into Vietnam in water

\footnotetext{
${ }^{1}$ Department of Environmental Management, College of Environment and Natural Resources, Can Tho University, Can Tho City, Viet Nam

Email: ntgiao@ctu.edu.vn

Received date: $29^{t h}$ February 2020; Revised date: $20^{\text {th }}$ March 2020; Accepted date: $5^{\text {th }}$ April 2020
}

management should be enhanced to solve continuing water problems.

Keywords: An Giang Province, cluster analysis, coliforms, pollution, Tien and Hau rivers, water quality.

\section{INTRODUCTION}

An Giang Province is located in the south of Vietnam and is situated downstream of the Mekong River. The 'downstream' of the Mekong River is considered to be from Tan Chau (Tien river) and Chau Doc (Hau river) to the sea. The Mekong River water flow is more than 500 billion $\mathrm{m}^{3}$ to the sea each year at a distribution ratio of $80 \%-20 \%$ with a flow of about $11,000 \mathrm{~m}^{3} / \mathrm{s}$ on the Tien river and about $2,650 \mathrm{~m}^{3} / \mathrm{s}$ on the Hau river [1]. However, after crossing the Vam Nao river, a large amount of water is transferred from the Tien river to the Hau river, with the average water flow of the two rivers almost equal $(51 \%$ and $49 \%$, respectively) [1]-[3]. The water level and flow rate on the Tien river are higher than that of Hau river, with the average flow velocity during the flood season being $2.7 \mathrm{~m} / \mathrm{s}$ (2004) with the highest and lowest water levels being -0.56 $\mathrm{m}$ (2005) and $4.82 \mathrm{~m}$ (2002), respectively; while on the Hau river, the flow velocity was about $1-2.98 \mathrm{~m} / \mathrm{s}$ and the water level ranged from -0.68 (2005) to $4.91 \mathrm{~m}$ (1937) [4]. In addition, on the Tien river, the average sediment content in flood season was about $800 \mathrm{~g} / \mathrm{m}^{3}$ and $250 \mathrm{~g} / \mathrm{m}^{3}$ on the Hau river, these differences were due to topography and characteristics of each area. Therefore, socioeconomic activities take place favorably because of the abundance of water resources 
supplied by Tien and Hau rivers which are downstream of the Mekong river. At present, water monitoring stations have been set up on Tien and Hau rivers to continuously monitor changes in water quality, however, long-term evaluation of water quality on these rivers has not been reported. In addition, there is no study on the monitoring frequency based on water quality data. This study aimed to find out water quality problems and evaluate the current frequency of water monitoring. The findings could help local water quality managers to adjust water monitoring plans at the studied stations.

\section{BACKGROUND}

There are a range of diverse economic activities such as agriculture, forestry, industry, and related services in An Giang province. Rice production and aquaculture have significantly contributed to the local and national development. According to the national environment report [5], the Mekong Delta had 61 industrial areas in 13 provinces. Most of the industrial parks are located along the Tien and Hau rivers [6]. Therefore, improper treatment of wastewater discharge is one of the main sources of water pollution in both rivers. Thus, high water quality monitoring in these rivers is paramount. Water monitoring systems have been set up since 2009 to monitor the water quality in southern Viet nam, especially on the Hau and Tien rivers. However, the frequency and stations of surface water quality monitoring have been established mainly based on budget allocation, human resources, and discharging entities. A scientific basis for setting up water quality monitoring systems is essential for improving monitoring. Cluster analysis (CA) has been widely used for assessing water quality variations over time [7] in rivers [8] and lakes [9]. CA is also used to establish the location and frequency of surface water monitoring [10]. This study aimed to evaluate changes in surface water quality and recommend monitoring frequency using continuous monitoring data of the three stations in An Giang Province over a period of 10 years from 2009 to 2018.

\section{MATERIALS AND METHODS}

The data of surface water quality was collected over ten years, 2008 to 2018. Annually the water variables were assessed each month. The collected surface water quality station locations were the MT1 station $\left(10^{\circ} 54^{\prime} 36.982^{\prime \prime} \mathrm{N}\right.$ and $105^{\circ} 9^{\prime} 47.035^{\prime \prime} \mathrm{E}$; the site locating upstream of Tien River monitoring the quality of water from Cambodia flowing into the Tien River), MH1 station $\left(10^{\circ} 57^{\prime} 19.798^{\prime \prime} \mathrm{N}\right.$ and $105^{\circ} 5^{\prime} 1.472^{\prime \prime} \mathrm{E}$; monitoring the water quality flowing from Cambodia into Hau river), and $\mathrm{MH} 2$ station $\left(10^{\circ} 19^{\prime} 31.887^{\prime \prime} \mathrm{N}\right.$ and $105^{\circ} 29^{\prime} 40.922^{\prime \prime} \mathrm{E}$; located on the Hau River at the junction between An Giang and Can Tho for monitoring the impact of An Giang's socio-economic activities). The water quality parameters measured were temperature $\left({ }^{\circ} \mathrm{C}\right), \mathrm{pH}$, dissolved oxygen $(\mathrm{DO}, \mathrm{mg} / \mathrm{L})$, total suspended solids (TSS, $\mathrm{mg} / \mathrm{L})$, nitrate $\left(\mathrm{N}-\mathrm{NO}_{3}^{-}, \mathrm{mg} / \mathrm{L}\right)$, orthophosphate $\left(\mathrm{P}_{-} \mathrm{PO}_{4}^{3-} \mathrm{mg} / \mathrm{L}\right)$, chemical oxygen demand (COD, $\mathrm{mg} / \mathrm{L})$, and coliforms (MPN/100 mL). Water quality was evaluated by comparing individual water quality parameters to those reported by National Technical Regulation on surface water quality (QCVN 08-MT: 2015/BTNMT) [11]. The difference in the mean values during the 10-year survey was tested by Analysis of Variance (ANOVA) using IBM SPSS statistics for Windows, Version 20.0 (IBM Corp., Armonk, NY, USA) at a 5\% significance level.

Cluster Analysis (CA) was applied to group surface water quality on Tien and Hau rivers over time (monthly) according to Ward's method [12]. The months showing samples with similar water quality were grouped into one cluster and, vice versa, for different water quality samples. The CA results were presented by a dendrogram [8], 
[13]. The results were then used to propose sampling frequency for water monitoring data by selecting one representative month in the same cluster of the same water quality [8], [12], [13]. In this study, CA was performed using 10-year continuous water quality monitoring data, monthly with eight water quality parameters. The copyrighted software, Primer 5.2 for Windows (PRIMERE Ltd, Plymouth, UK) was utilized in this study.

\section{RESULTS AND DISCUSSION}

A. Evaluating surface water quality on Tien and Hau rivers for the period of 2009 to 2018

\section{Temperature}

Figure 1 shows the mean annual water temperatures at the three sampling stations from 2009 to 2018. The temperatures detected at MT1 ranged from $28.07 \pm 0.66^{\circ} \mathrm{C}$ to $30.39 \pm 1.30^{\circ} \mathrm{C}$. The highest temperature $\left(30.39 \pm 1.30^{\circ} \mathrm{C}\right)$ was in 2009 , which is also the year with the largest fluctuation probably due to seasonal influence. The mean surface water temperature at $\mathrm{MH} 1$ in this period varied from $23.09 \pm 1.21^{\circ} \mathrm{C}$ to $30.14 \pm 0.99^{\circ} \mathrm{C}$, in which, the average temperature in 2016 was relatively low $\left(23.09 \pm 1.21^{\circ} \mathrm{C}\right)$. The mean water environment temperature in the Hau river at the section adjacent to Can Tho City at the station $\mathrm{MH} 2$ over the years from 2009 to 2018 fluctuated from $27.86 \pm 1.56^{\circ} \mathrm{C}$ to $30.25 \pm 1.13^{\circ} \mathrm{C}$. There was almost no statistically significant difference during the surveyed years ( $>0.05)$, except in 2009 and 2016. In general, the mean ranges of water temperatures at the three monitoring stations are suitable for aquatic life in the region [14], consistent with the previous studies on the two rivers [15]. The monitoring results in the period of 2009 to 2018 also showed that the temperatures in March (dry season) and September (wet season) were not significantly different at any of the stations (MT1 in the range of $28.93 \pm 1.62^{\circ} \mathrm{C}$ in March and $28.84 \pm 0.70^{\circ} \mathrm{C}$ in September; $\mathrm{MH} 1$ in the range of $28.10 \pm 2.87^{\circ} \mathrm{C}$ in March and $27.50 \pm 3.06^{\circ} \mathrm{C}$ in September; at $\mathrm{MH} 2$ in the range of $29.36 \pm 1.91^{\circ} \mathrm{C}$ in March and 29.16 $\pm 0.89^{\circ} \mathrm{C}$ in September). This coincides with the reports from the Department of Natural Resources and Environment of Tien Giang (DONRE Tien Giang, 2017) and Lien et al. [16], [17] which stated that the downstream areas of Tien and Hau rivers have temperatures ranging from 28.10 to $32.80^{\circ} \mathrm{C}$ and 27.10 to $32.0^{\circ} \mathrm{C}$ respectively, and this value shows that there was almost no significant change between upstream and downstream areas on the Tien River.

\section{pH}

In water, $\mathrm{pH}$ affects the solubility and the reaction of pollutants, so $\mathrm{pH}$ is an important factor in explaining the variability of substances [18]. The $\mathrm{pH}$ values at the MT1, $\mathrm{MH} 1$ and $\mathrm{MH} 2$ stations were $6.6 \pm 0.2$ to 7.3 $\pm 0.3 ; 6.3 \pm 0.6$ to $7.3 \pm 0.2$ and $6.6 \pm 0.2$ $7.4 \pm 0.2$, respectively (Figure 2). The $\mathrm{pH}$ values in 2009 were significantly different to the years 2010 and 2014 ( $p<0.05$ ), but the $\mathrm{pH}$ was within the permissible limit of QCVN 08-MT: 2015/BTNMT [11] states that a $\mathrm{pH}$ between 6 to 8.5 at, column $\mathrm{A} 1$, the river water can be used for domestic purposes. Aso, according to Dien et al. [19] $\mathrm{pH}$ values in both the Tien and Hau rivers ranged from 7.1 to 7.4 , and in the period of 20092016 , the $\mathrm{pH}$ values in Tien and Hau rivers ranged from $6.7 \pm 0.1$ to $7.4 \pm 0.1$ and $6.8 \pm$ 0.2 to $7.3 \pm 0.1$ [15]. This demonstrates that the $\mathrm{pH}$ value has begun to decrease over time. However, if comparing the $\mathrm{pH}$ value at MT1 and $\mathrm{MH} 1$ in the study with the upstream area of the Tien river ( $\mathrm{pH}$ ranged from 6.1 to 7.9) and the Hau river (6.3 to 8.0, with an average of 7.1) [6], [16], [17], it could be noted that the $\mathrm{pH}$ value increased gradually towards the end of the An Giang Province border to Can Tho City. The data shows that the values of $\mathrm{pH}$ in these rivers do not change significantly over the years of observation, the reason was that the annual flow and buffering capacity of the river water are relatively large, so the 


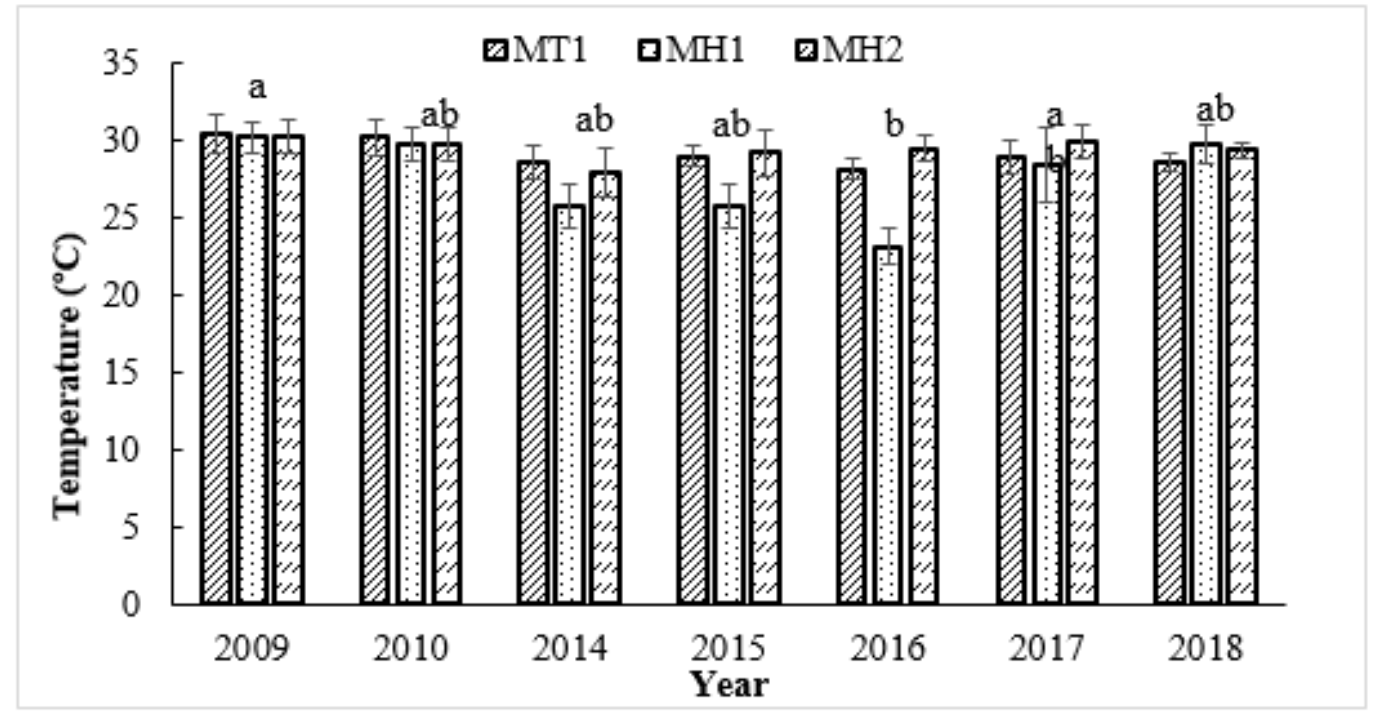

Fig. 1: Mean temperature at the monitoring stations for the period of 2009 to 2018

$\mathrm{pH}$ has little change.

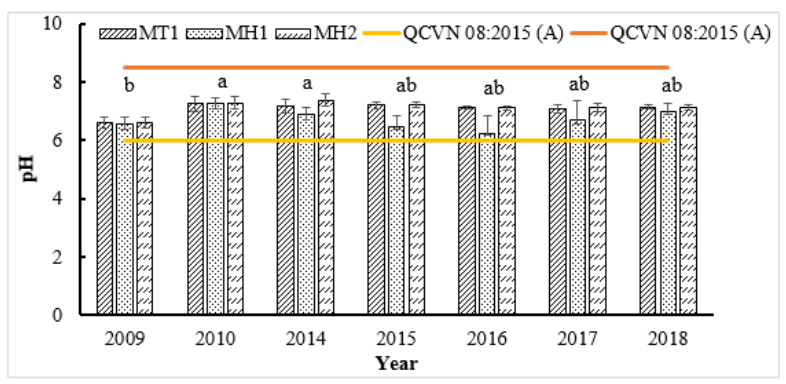

Fig. 2: Mean $\mathrm{pH}$ at the monitoring stations for the period of 2009 to $2018 \mathrm{pH}$

\section{Total suspended solids}

The averaged suspended solids (TSS) at the sampling locations ranged from $44.94 \pm$ 33.62 to $68.46 \pm 61.38 \mathrm{mg} / \mathrm{l}$ at MT1, from $38.77 \pm 31.24$ to $67.14 \pm 57.93 \mathrm{mg} / \mathrm{l}$ at $\mathrm{MH} 1$ and from $39.5 \pm 35.46$ to $55.98 \pm 23.43 \mathrm{mg} / \mathrm{l}$ at the MH2 (Figure 3). In particular, in the year 2010 there was a concernable difference compared to the data from 2009 and 2015 (p $<0.05)$. The TSS at the monitoring stations exceeded the permitted level compared with QCVN 08-MT: 2015/BTNMT in column A [11], where the TSS content detected at the
Tien and Hau rivers in the downstream area was $91.2 \mathrm{mg} / \mathrm{L}$ and $51.5 \mathrm{mg} / \mathrm{l} \mathrm{[6],} \mathrm{[17],}$ and tended to increase downstream. TSS did not show any signs of decrease in either the Tien and Hau rivers over time. High concentrations of TSS can result in a decline of water quality and an increase in treatment of water for domestic use. The causes of high suspended solids could be from waterway transport, erosion and stormwater runoff [15]. The suspended solids data at stations MT1 and MH1 showed that high levels of suspended solids in river water are not only a problem for Viet Nam but also for the countries that the Mekong river runs through

\section{Dissolved oxygen}

Variations in dissolved oxygen (DO) is present in a water environment mainly due to the photosynthesis of aquatic plants and diffusion from air into a water environment [20]. The average DO content in river water was about $7 \mathrm{mg} / \mathrm{l}$ at $25^{\circ} \mathrm{C}$, and the higher the temperature the lower the DO is due to the water being susceptible to saturation [21]. In this study, DO concentrations observed at the sampling locations over 10 years are 


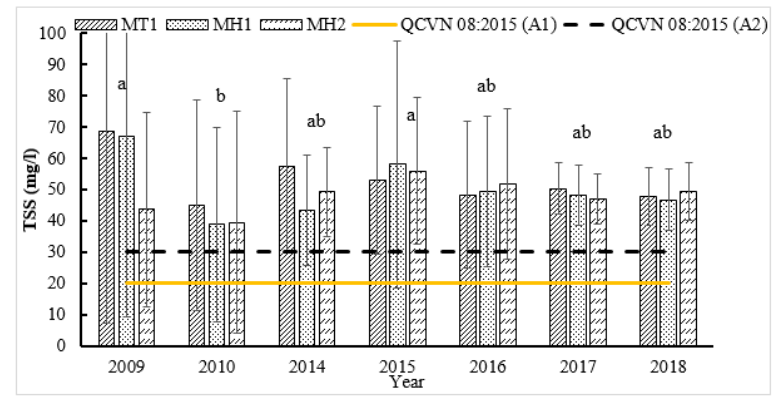

Fig. 3: Mean TSS at the monitoring stations for the period of 2009 to 2018

presented in Figure 5. The mean DO at the MT1 station ranged from $4.82 \pm 0.94$ to 6.47 $\pm 0.55 \mathrm{mg} / \mathrm{l}, \mathrm{MH} 1$ from $4.67 \pm 1.15$ to 5.51 $\pm 0.68 \mathrm{mg} / \mathrm{l}$, and $\mathrm{MH} 2$ from $4.56 \pm 0.80$ to $6.08 \pm 0.39 \mathrm{mg} / \mathrm{l}$. It can be seen that most of the data from 2009 has the lowest concentrations compared to the other years, therefore 2009 has a statistically significant difference $(\mathrm{p}<0.05)$. Concentrations of DO on the Tien and Hau rivers reported in 2012 ranged from 4.89 to $6.61 \mathrm{mg} / \mathrm{l}$ [19], which was consistent with the study over the other years of the survey, this is consistent with studies of other authors [22] which reported that DO on the lower Mekong River ranged from 5 to $8.25 \mathrm{mg} / \mathrm{L}$, and averaged $6.60 \pm$ $0.90 \mathrm{mg} / \mathrm{l}$. On the other hand, according to research by Dieu et al. [6]; DONRE Tien Giang [16] and Lien et al. [17] at basins upstream the DO concentration in the water ranged from 3.30 to $4.81 \mathrm{mg} / \mathrm{l}$ on the Tien river and 5.10 to $5.50 \mathrm{mg} / \mathrm{l}$ on the Hau river, where the presence of TSS and water velocity in the basins could be the cause of the DO difference between locations. However, there were no significant differences between the sampling stations upstream and downstream, and this result was consistent with data reported by Lien et al. [17].

At most times and stations, DO met the regulating value in column $\mathrm{A} 2$ (DO $\geq 5$ $\mathrm{mg} / \mathrm{l}$ ) but not column $\mathrm{A} 1$ (DO $\geq 6 \mathrm{mg} / \mathrm{l}$ ) in the technical national regulation on surface

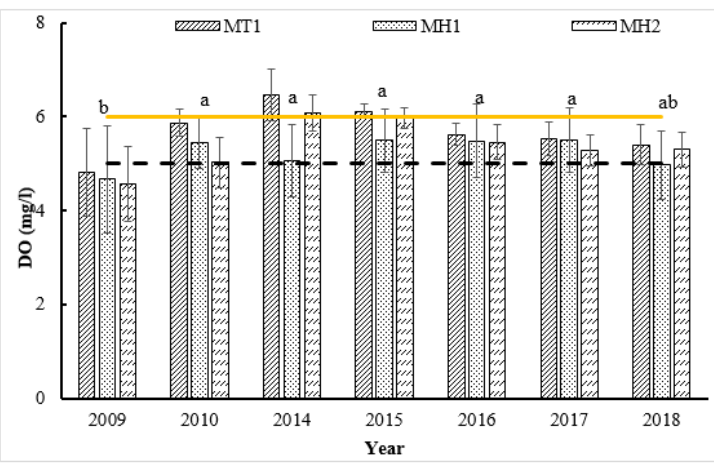

Fig. 4: Mean DO at the monitoring stations for the period of 2009 to 2018

water (QCVN 08-MT: 2015/BTNMT) [11]. The DO in 2009 did not meet the Vietnamese standards on surface water quality represented by column A. The overall data of DO demonstrated that surface water on both Tien and Hau rivers was organically polluted. The cause of organic pollution in the rivers could be attributed to agricultural production, livestock and living activities [15], [23].

\section{Chemical oxygen demand}

Variations of chemical oxygen demand (COD) at the monitoring stations are depicted in Figure 5. The COD at the MT1 station ranged from $6.35 \pm 1.47$ to $13.58 \pm 3.90$ $\mathrm{mg} / \mathrm{l}, \mathrm{MH} 1$ varied from $6.96 \pm 1.69$ to 13.18 $\pm 3.70 \mathrm{mg} / \mathrm{l}$ and $\mathrm{MH} 2$ fluctuated from 6.46 $\pm 2.19 \mathrm{mg} / \mathrm{l}$ to $13.15 \pm 2.91 \mathrm{mg} / \mathrm{l}$. The COD concentration at different positions increased and decreased dramatically ( $\mathrm{p}<0.05$ ), but in 2009 to 2010 and 2014 to 2015 there was no difference $(\mathrm{p}>0.05)$. The concentration of COD from 2009 to 2010 was low and met the permissible limit of QCVN 08-MT: 2015/BTNMT, Column A1 [11]. COD in the rivers from 2014 to 2018 did not meet the permitted standard. According to the results environmental monitoring in 1998, the COD concentration on the Hau River was about $5.0 \mathrm{mg} / \mathrm{l}$ [24], higher than this study at the MH1 station. Also the COD content in the upstream area of the Tien and Hau rivers 
tended to be higher than the upstream, with concentrations ranged from 5.0 to $14.50 \mathrm{mg} / \mathrm{l}$ and 8.0 to $19.0 \mathrm{mg} / \mathrm{l}$ [6], [17]. Moreover, a trending increase was found for COD in the rivers from 2009 to 2018. This is consistent with the $2012 \mathrm{~N}$ ational Environmental Status Report [5], the surface water quality of the Mekong Delta was organically polluted due to the impact of wastewater generated from industrial activities, aquaculture and seafood processing, and agricultural cultivation. Ly and Giao [15] reported that biological oxygen demand (BOD) in the rivers and canals in An Giang Province was polluted by organic matters since BOD was found ranging from $6.6 \pm 1.2$ to $8.2 \pm 2.5 \mathrm{mg} / \mathrm{l}$, and averaged at $7.4 \pm 2.2 \mathrm{mg} / \mathrm{l}$ which was higher than the permissible level at $4.0 \mathrm{mg} / \mathrm{l}$ (QCVN 08-MT: 2015/BTNMT, Column A1) [11]. It could be stated that the problem of organic pollution is still ongoing in both Tien and Hau rivers.

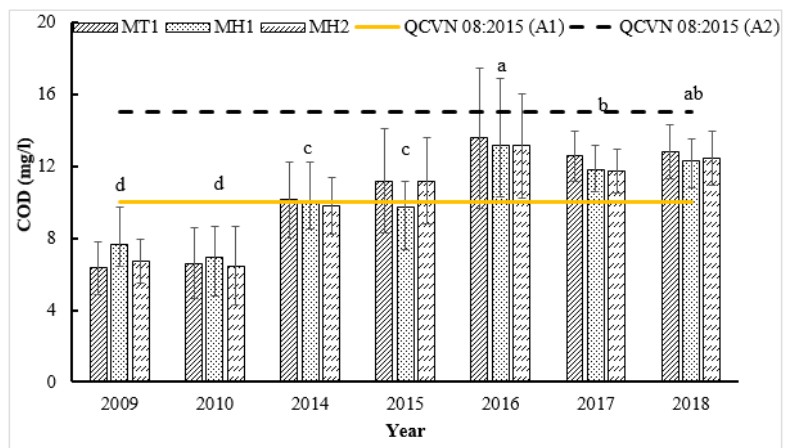

Fig. 5: Mean COD at the monitoring stations for the period of 2009 to 2018

\section{Nitrate}

Nitrate concentrations in the Tien and Hau rivers for 10 years (2009-2018) ranged from $0.04 \pm 0.03$ to $0.10 \pm 0.04 \mathrm{mg} / \mathrm{l}$ (Figure 6) which were in accordance with aprior study on water quality in rivers and canals of An Giang Province indicating that nitrate concentrations ranged from $0.31 \pm 0.30$ to $0.58 \pm 0.64 \mathrm{mg} / 1$ [15]. In the same sampling area, there was a difference between 2016 and 2014 ( $p$ <0.05). Nitrate content in the natural environment is usually $<5 \mathrm{mg} / \mathrm{l}$ [25], [26]; this can be seen in that the nitrate content in the study area was quite low, and there was no sign of pollution. Nitrate content in the upstream area in 2016 and 2017 ranged from 0.40 to $0.61 \mathrm{mg} / \mathrm{l}$ (Tien river); 0.12 to $0.41 \mathrm{mg} / \mathrm{l}$ (Tien river) and 0.002 $0.0395 \mathrm{mg} / \mathrm{l}$ (Hau river), which tended to be higher than the upstream area in this study [6], [16], [17]. According to Boyd (1998) [27], nitrate concentration that is suitable for aquaculture is from 0.20 to $10.0 \mathrm{mg} / \mathrm{l}$ and nitrate concentrations of greater than 0.70 $\mathrm{mg} / \mathrm{l}$ could lead to eutrophication [28]. The nitrate concentrations in the current study was still within the permitted limits of QCVN 08-MT: 2015/BTNMT (column A1, 2 mg/L) [11]. This could mean that the nitrate in the water rivers would not affect human health and ecosystems.

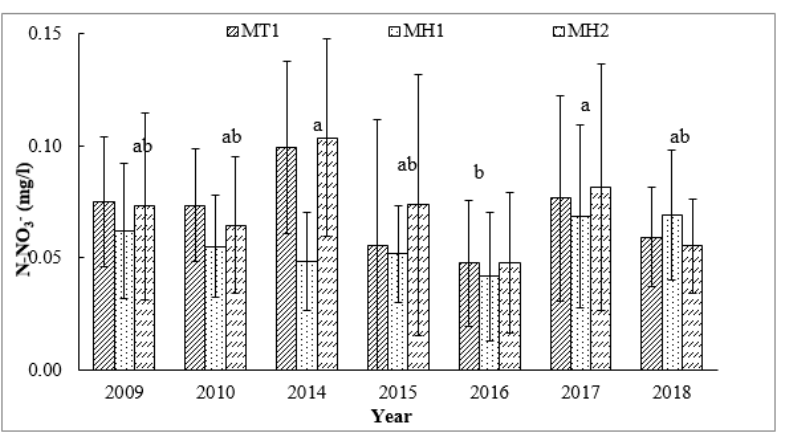

Fig. 6: Mean nitrate at the monitoring stations for the period of 2009 to 2018

\section{Orthophosphate}

The concentrations of orthophosphate (P$\left.\mathrm{PO}_{4}^{3-}\right)$ in the Tien and Hau rivers during the period of 2009 to 2018 are presented in Figure 7.

At the MT1 station, $\mathrm{P}_{-} \mathrm{PO}_{4}^{3-}$ ranged from $0.03 \pm 0.02$ to $0.16 \pm 0.15 \mathrm{mg} / \mathrm{l}, \mathrm{MH} 1$ from $0.04 \pm 0.03$ to $0.43 \pm 1.15 \mathrm{mg} / \mathrm{l}$, and $\mathrm{MH} 2$ from $0.05 \pm 0.03$ to $0.80 \pm 2.32 \mathrm{mg} / \mathrm{l}$. Orthophosphate at MH2 (in 2009, 2010, and 2016) and at MH1 (in 2014 and 2015) exceeded the allowable threshold specified in 
QCVN 08-MT: 2015/BTNMT, column A1 $(0.10 \mathrm{mg} / \mathrm{l})$ and column A2 (0.20 mg/l) [11]. A previous study in An Giang Province showed that the concentration of dissolved phosphorus in the Tien River ranged from 0 to $0.2 \pm 0.1 \mathrm{mg} / \mathrm{l}$, Hau River varied from 0 to $0.2 \pm 0.0 \mathrm{mg} / \mathrm{l}$, and in-field canals from 0.02 to $0.47 \mathrm{mg} / \mathrm{L} \mathrm{[15].} \mathrm{In} 2016$ and 2017 in the downstream area, the final phosphate concentration on the Tien and Hau rivers varied dramatically from 0.04 to $0.079 \mathrm{mg} / \mathrm{l}$; 0.06 to $0.43 \mathrm{mg} / \mathrm{l}$ and 0.007 to $0.51 \mathrm{mg} / 1$ [6], [16], [17]. Moreover, the study by Nguyen [29] also showed that the water quality on Hau river $\mathrm{P}_{-} \mathrm{PO}_{4}^{3-}$ ranged from 0.017 - 0.415 $\mathrm{mg} / \mathrm{l}$. The presence of orthophosphate could pose a high risk of eutrophication of rivers, causing plants like the water hyacinth to overgrow, which obstructs traffic and pollutes the water environment. By 2017, the concentration of $\mathrm{P}_{-} \mathrm{PO}_{4}^{3-}$ decreased to a level lower than the value that is regulated by QCVN 08-MT: 2015/BTNMT, column A1 $(0.1 \mathrm{mg} / \mathrm{l})$ [11]. However, by the year 2018, the dissolved phosphorus in Tien and Hau rivers had approached the regulated value by QCVN 08-MT: 2015/BTNMT, column A1 [11], which could potentially pose a risk of water quality degradation.

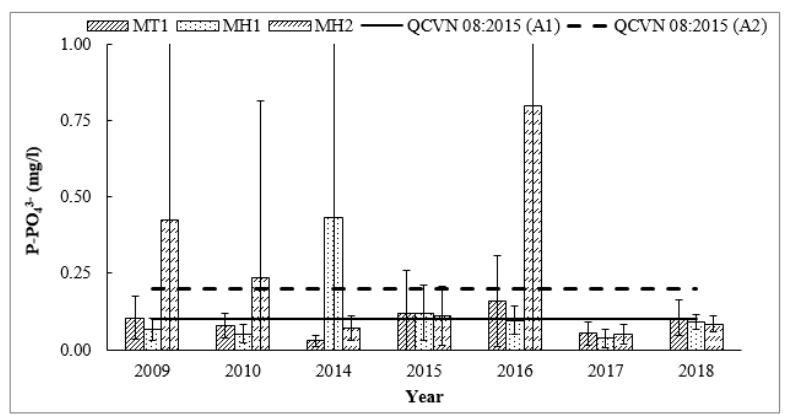

Fig. 7: Mean $\mathrm{P}_{-} \mathrm{PO}_{4}^{3-}$ at the monitoring stations for the period of 2009 to 2018

\section{Coliforms}

The densities of coliforms at the monitoring stations in both Tien and Hau rivers in the period of 2009 to 2018 (Figure 8) exceeded the permitted threshold of QCVN 08-MT: 2015/BTNMT from 5.9 to 17.1 times [11], significant differences $(\mathrm{p}<0.05)$ in 2017 for the remaining years. Coliforms at MH1 $\left(1.01 \times 10^{4}\right.$ to $\left.1.04 \times 10^{5} \mathrm{MPN} / 100 \mathrm{ml}\right)$ was always higher than MT1 $\left(4.57 \times 10^{3}\right.$ to $\left.8.44 \times 10^{4} \mathrm{MPN} / 100 \mathrm{ml}\right)$ and $\mathrm{MH} 2\left(7.38 \times 10^{3}\right.$ to $3.18 \times 10^{4} \mathrm{MPN} / 100 \mathrm{ml}$ ) indicating strong influence of fecal materials from upstream of the Mekong river. In the downstream Tien river, the coliform density in 2017 was recorded, which varied from $3.6 \times 10^{4}$ to $2.2 \times 10^{5} \mathrm{MPN} / 100 \mathrm{ml}$ [16] which tended to be higher than that detected upstream. The study by Dien et al. [19] also reported that the coliform density on the Tien river in 2011 to 2012 was lower than in Hau river, varied from $1.0 \times 10^{4}-1.2 \times 10^{4} \mathrm{MPN} / 100 \mathrm{ml}$. Therefore, the former study that had reported that rivers and canals in An Giang Province were microbially contaminated could be recognized by the densities of coliforms and that which exceeded the permitted level from 2.1 to 7.0 times [15]. The data describing microbiological pollution shows that management of human and animal waste is not appropriate or existent in this area. The presence of high density coliforms at the monitoring stations could lead to a serious impact on water quality, and therefore adversely affect human health and the surrounding ecosystems which require effective management of river water quality. The above analysis showed that coliform pollution is a problem that needs attention in both the Tien and Hau rivers.

Examination of surface water quality at the three continuous monitoring stations revealed that the water has serious problems with total suspended solids, chemical oxygen demand, and coliforms. The data at MT1 and MH1 presented that the water has been seriously contaminated before flowing into An Giang Province. This leads to an urgent need to collaborate with the countries upstream of the Mekong river to improve surface water quality. 


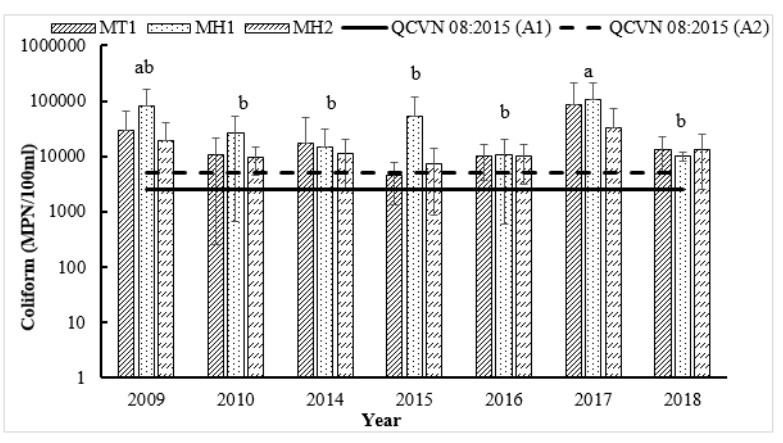

Fig. 8: Mean coliform density at the monitoring stations for the period of 2009 to 2018

\section{B. Evaluating surface water quality monitor- ing frequency at MT1, MH1 and MH2}

The cluster analysis (CA) result using the 10 -year continuous water quality monitoring data, every month of the year, and eight water quality parameters at the MT1, the site upstream of the Tien river, is presented in Figure 9. The results indicate that the current monitoring frequencies of 12 times per year could be divided into four clusters. Cluster 1 includes the months from April to October, in which the months of July to October are during the rainy season, and April to June encompass the months of the end of the dry season and the beginning of the rainy season. Cluster 2 includes November and December, which represents a transition period from the rainy season to the dry season. Cluster 3 is comprised of the months January and March belonging to the dry season months. Finally, cluster 4 includes only the month of February. The frequency of water monitoring at the MT1 station could be established by selecting one of the months in each cluster since there is no difference in water quality in the same cluster. Therefore, the five representative months of the clusters, for example, February, March, June, September and December should only be selected for optimum water quality monitoring.

The water quality at the MH1 station was classified into three to five clusters (b).
In this case where the current monitoring frequency was divided into three clusters (blue line). Cluster 1 included the months of January and March to August corresponding to the dry season and early rainy season. Cluster 2 comprised only the month of February, which is the dry season. Cluster 3 included July to December which is the rainy season and early dry season. In the case of five clusters as indicated in Figure 10, cluster 1 included January and March to May and cluster 2 from June to August, cluster 3 comprised only of February, cluster 4 included July, September and October, and lastly cluster 5 comprised of November and December. Monitoring frequency should be selected based on the five clusters at the MT1 and it would be highly relevant for this station MH1 to also select water monitoring frequency following the five classified clusters seen in Figure 10. The representative months for the site MH1 could be February, March, June, September and December, the months that are proposed for this monitoring station are the same as the months recommended at MT1 station.

Twelve months of water quality monitoring at station $\mathrm{MH} 2$ were grouped using $\mathrm{CA}$ and the result is shown in Figure 11. Similar to the station $\mathrm{MH} 1$, water quality at $\mathrm{MH} 2$ could be classified into three to five clusters. In the case of dividing into three clusters (blue line, Figure 11), cluster 1 included January and March, cluster 2 has only the month of June, whereas cluster 3 included February, April, November, December, May, and July to October. In the case of a five cluster analysis (orange line, Figure 11), cluster 1 had only the month of January, cluster 2 comprised only of March, cluster 3 included only June, cluster 4 February, April, November and December and finally cluster 5 comprised May and July to October.

Similar to the MH1 station, the representative months for water quality monitoring at $\mathrm{MH} 2$ should comprise of January, February, March, June, September and December. 


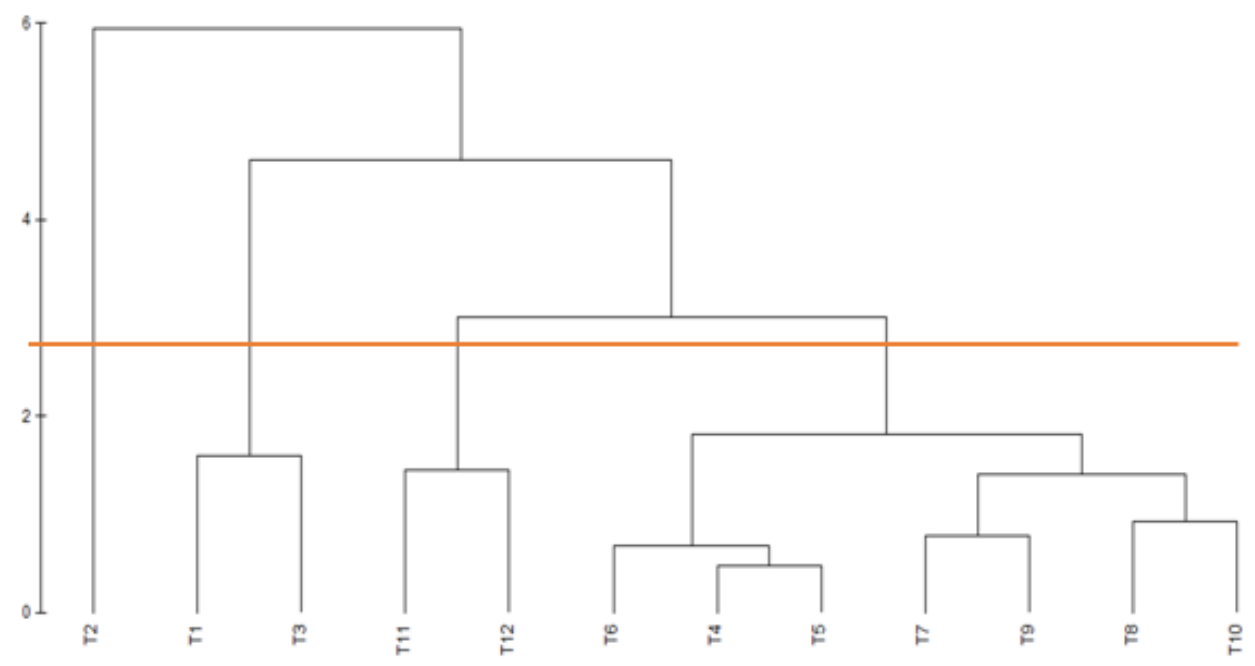

Fig. 9: Cluster analysis of surface water quality at MT1

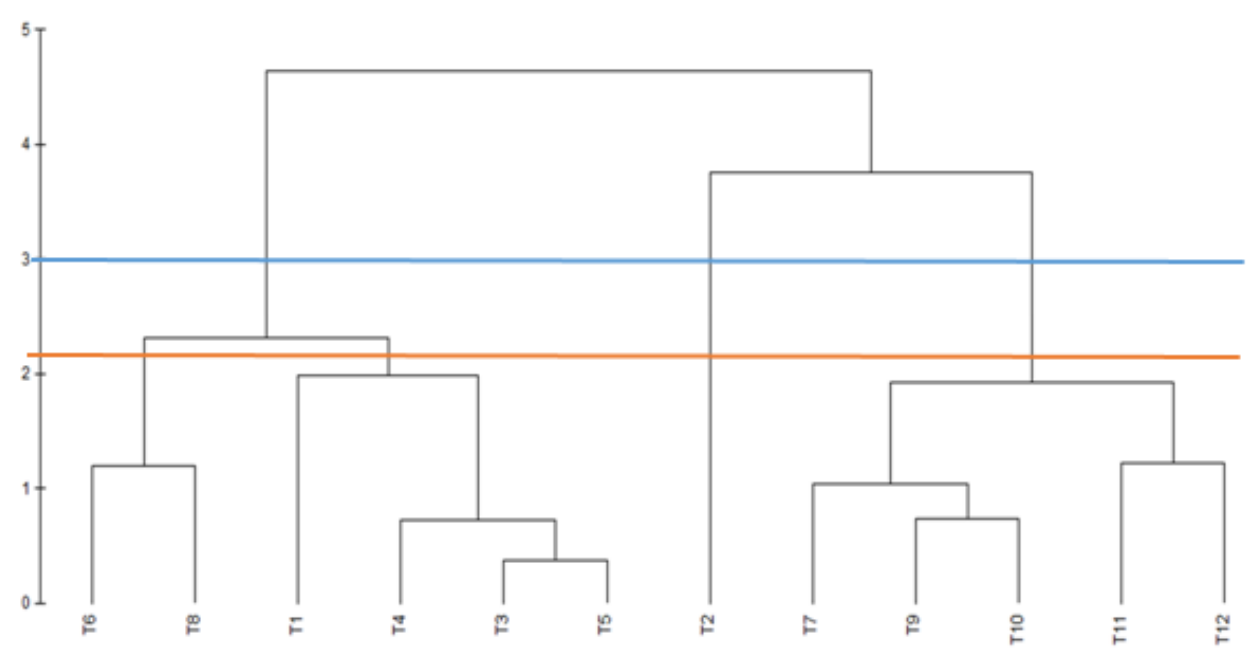

Fig. 10: Cluster analysis of surface water quality at MH1

However, January and March are in the same cluster (blue line, Figure 11), therefore March could be potentially used for monitoring instead of both January and March. In short, five months including February, March, June, September and December should only be selected for optimal water quality monitoring at the stations MT1, MH1 and MH2.

\section{CONCLUSION}

The findings of the present study show that the use of surface water on Tien and Hau rivers is hindered by the excessive amounts of suspended solids, organic matters, nutrients and microorganisms. The sources of water pollution could originate from socialeconomic activities from the upper parts of the Vietnamese Mekong river. Cluster analysis indicated that the current frequency of 


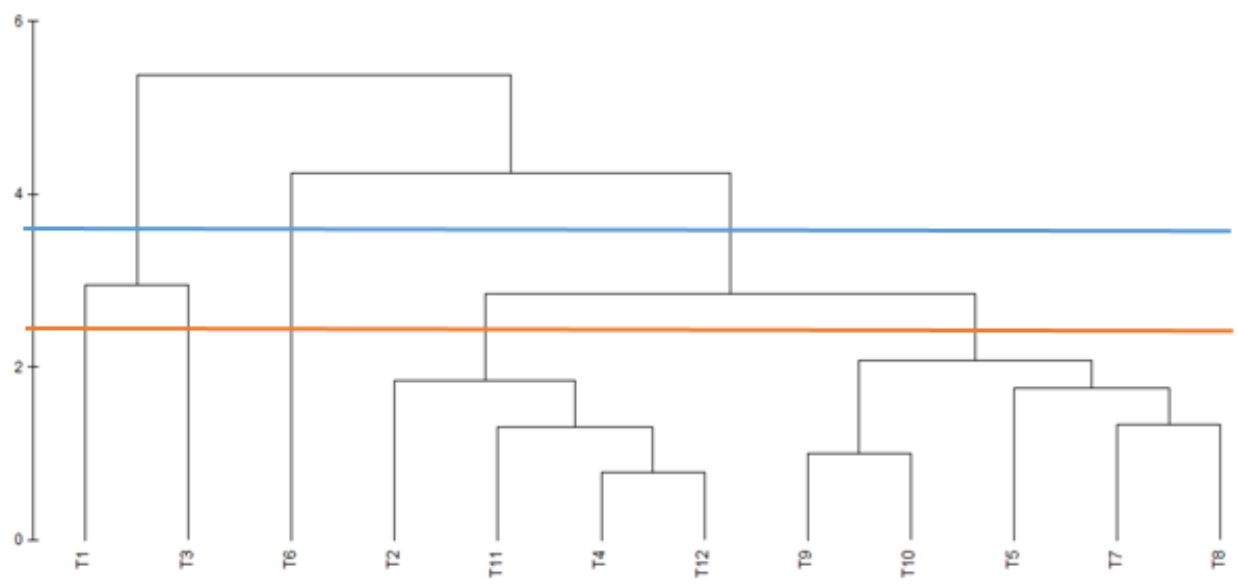

Fig. 11: Cluster analysis of water quality at $\mathrm{MH} 2$

monitoring at the three continuous monitoring stations could be reduced from every month of the year to 5 representative months which would be February, March, June, September and December. This leads to a $58 \%$ reduction in water quality monitoring costs. Improving water quality on the Tien and Hau rivers requires close coordination with the upstream Mekong countries since the water quality at the water border between Viet Nam and Cambodia (MT1 and MH1) was already polluted before flowing into Viet Nam.

Acknowledgement. The author would like to thank for the data provision from Department of Natural Resources and Environment of An Giang Province. Any opinions, findings, and conclusions or recommendations expressed in this material are those of the author and does not necessarily reflect the views of any agencies.

\section{REFERENCES}

[1] Tuan LA. The tital and the transmission of the tital into the Mekong River in Characteristics of methodology - hydraulic regional area of Mekong River. Can Tho University; 2004. 18 pages.

[2] Huy PDA, and Tu TT. Assess changes of river bank erosion the vicinity of Vam Nao. Science \& Technology Development. 2015;18(M2):13-21.
[3] The Netherlands Delta Development Team. Recommendations Concerning Agricultural Development with Improved Water Control In The Mekong Delta. Working paper IV: Hydrology; 1974.

[4] People's Committee of An Giang Province. Report on the state of environment in five years (2011 -2015) of An Giang Province; 2015.

[5] Ministry of Natural Resources and Environment. $\mathrm{Na}$ tional State of Environment-Surface Water Quality; 2012. 112 pages.

[6] Dieu HTQ, Phong NH, Hop NV. Study to assess water quality in Tien river. Journal of Chemistry, Physics and Biological Analysis. 2016;21(1):38-48.

[7] Zeinalzadeh K, Rezaei E. Determining spatial and temporal changes of surface water quality using principal component analysis. Journal of Hydrology: Regional Studies. 2017;13:1-10.

[8] Chounlamany V, Tanchuling MA, Inoue T. Spatial and temporal variation of water quality of a segment of Marikina river using multivariate statistical methods. Water Science and Technology. 2017;66(6):1510-1522.

[9] Cho KH, Park Y, Kang JH, Ki SJ, Cha S, Lee SW, Kim JH. Interpretation of seasonal water quality variation in the Yeongsan Reservoir, Korea using multivariate statistical analyses. Water Science \& Technology. 2009;59;2219-2226.

[10] Singh KP, Malik A, Sinha S. Water quality assessment and apportionment of pollution sources of Gomti river (India) using multivariate statistical techniques - a case study. Analytica Chimica Acta. 2005;538:355-374.

[11] Ministry of Natural Resources and Environment. $\mathrm{Na}$ tional technical regulation on surface water quality, QCVN 08-MT: 2015/BTNMT; 2015.

[12] Salah EAM, Turki AM, Othman EMA. Assessment of water quality of Euphrates River using clus- 
ter analysis. Journal of Environmental Protection. 2012;3:162-1633.

[13] Feher IC, Zaharie M, Oprean I. Spatial and seasonal variation of organic pollutants in surface water using multivariate statistical techniques. Water Science and Technology. 2016;74:1726-1735.

[14] Tien DV. Observe some water environmental factors in the Mekong Delta [Master thesis]. Specialized in Fisheries University of Agriculture and Forestry Ho Chi Minh city; 2012.

[15] Ly NHT, Giao NT. Surface water quality in canals in An Giang Province, Viet Nam, from 2009 to 2016. Journal of Vietnamese Environment. 2018;10(2):113119.

[16] Department of Environment and Natural Resources of Tien Giang. General reports on environmental monitoring results in 2017; 2018.

[17] Lien NTK, Huy LQ, Oanh DTH, Phu TQ, Ut VN. Water quality in mainstream and tributaries of Hau river. Can Tho University Journal of Science. 2016;43:68-79.

[18] Chi DK. Environmental chemistry. Hanoi, Viet Nam: Scientific and Technical Publisher; 2002.

[19] Dien LD, Lan MT, Hung ND. Status of water quality of canals on Tien and Hau river (2011-2012). Environment Magazine; 2016;7.

[20] Khoa LV. Environment and Pollution. Hanoi, Viet Nam: Education Publishing house; 1994.

[21] Varol M, Sen B. Assessment of surface water quality using multivariate statistical techniques: a case study of Behrimaz Stream, Turkey. Environmental Monitoring and Assessment. 2009;159:543-553.

[22] Giap DH, Kunpradid T, Vongsombath C, Loc DTB, Somany P. Report on the 2008 biomonitoring survey of the lower Mekong River and selected tributaries. MRC Technical Paper No.27 Mekong River Commission, Vientiane; 2010.

[23] Giao NT. The use of zoobenthos for the assessment of water quality in canals influenced by landfilling and agricultural activity. Journal of Vietnamese Environment. 2019;11(2):33-42.

[24] Ninh PV. Monitoring and evaluating the current state of the environment in An Giang. Department of Science, Technology and Environment of An Giang; 1998.

[25] Boyd CE, Green BW. Water quality monitoring in shrimp farming areas: an example from Honduras, Shrimp Farming and the Environment, Report prepared under the World Bank, NACA, WWF and FAO Consortium Program on Shrimp Farming and the Environment, Auburn, USA; 2002.

[26] Dang NH. Physical-chemical properties of $O$ Mon river water through Chau Van Liem ward, O Mon District, Can Tho City [Thesis graduated]. Department of Agriculture at Can Tho University; 2005.

[27] Boyd CE. Water quality for pond aquaculture. Research and Development Series, International Center for Aquaculture and Aquatic Environments, Auburn University; 1998.

[28] Ongley ED. Chapter 12: Water Quality of the Lower Mekong River. In: Campbell, I.C. (ed.): The Mekong: Biophysical Environment of an International River Basin. Academic Press, 4951 Connaught Ave. Montreal, QC, Canada H4V 1X4. 2009:297-320.

[29] Nguyen TT. Fluctuation of water quality on Hau River [Master's thesis]. Can Tho University; 2013. 